AIR COMMAND AND STAFF COLLEGE

AIR UNIVERSITY

\title{
WARLORDS OF THE SOMALI CIVIL WAR (1988-1995)
}

\author{
by \\ Gideon S. Hall, Major, USAF \\ A Research Report Submitted to the Faculty \\ In Partial Fulfillment of the Graduation Requirements for the Degree of \\ MASTER OF OPERATIONAL ARTS AND SCIENCES
}

Advisor: Dr. Charles Thomas

Maxwell Air Force Base, Alabama

April 2015 


\section{Disclaimer}

The views expressed in this academic research paper are those of the author(s) and do not reflect the official policy or position of the US government or the Department of Defense. In accordance with Air Force Instruction 51-303, it is not copyrighted, but is the property of the United States government. 
Table of Contents

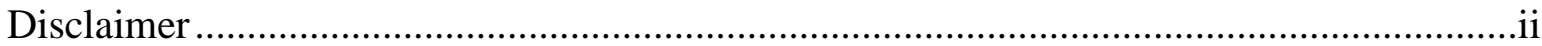

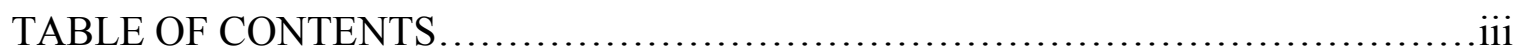

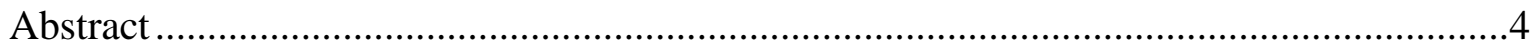

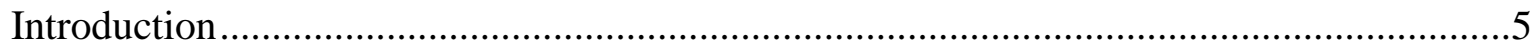

General Mohamed Farah Hassan Aideed and United Somali Congress .............................8

Ali Mahdi Mohammed and United Somali Congress ....................................................11

Mohammed Said Hersi Morgan and the Somali National Front ......................................13

Ahmed Omar Jess and the Somali Patriotic Movement ...............................................14

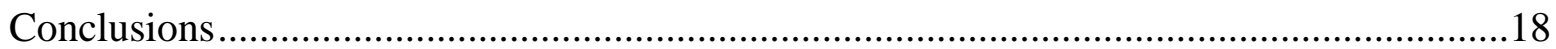

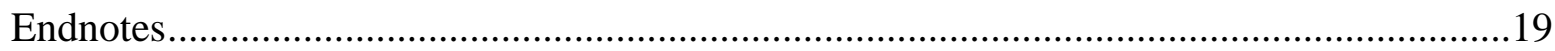

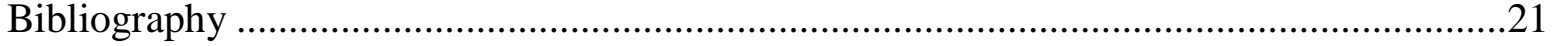




\begin{abstract}
This paper argues that following the fall of Mohammed Siad Barre's regime, leaders of different opposition groups mobilized the government, military, and clan structures towards their own political ends, leading to renewed conflict. Two primary protagonists dominated the Somali Civil War; General Mohammed Farah Aideed and Ali Mahdi Mohammed. Secondary protagonists were Mohammed Said Hersi Morgan and Ahmed Omar Jess. Each warlord used the factions they led, the Somali government, military and people as instruments for pursuing their political interest. Each political leader's interests and the instruments they used to pursue those interests will be analyzed in three categories: government, military and people. The Somali National Front, the Somali Patriotic Movement and the United Somali Congress are the three factions the aforementioned leaders led. Most of these groups were bred out of Somali National Movement. ${ }^{1}$ As groups with various interests/agenda emerged, I intend to explain how the faction leaders functioned as political entities inculcating a culture of violence and depravity.
\end{abstract}




\section{- Introduction}

The Republic of Somalia is located in the Horn of Africa and bordered by Djibouti, Ethiopia and Kenya. Water constitutes the remaining border with the Gulf of Aden in the north and the Indian Ocean comprising the eastern seaboard. Somalis share a common ethnic identity, language and religion. The foundation of the political system was family and family ties. ${ }^{2}$ Family relations underpinned larger units such as sub-clans that belonged to clans. ${ }^{3}$ Commonly considered a patron-client network, before and during the civil war, Somalis fell into two categories: individuals were either a part of the patrimonial network or outside of it. If part of the network, individuals accepted the rule of the leader and exerted power over clients. These clients exerted power over other clients. As an outsider to the patron-client network, Somalis typically had little or no claim to power or authority where deposing those in the network was the only alternative. When no clan lineage was identified, Somalis were significantly more vulnerable and thus subjected to persecution. In Somalia, patron-client networks were largely based on clan alignment and the favors granted by an empowered Somali leader. There were six main clans in Somalia: Hawiye, Isaq, Dir, Darod, Rahanweyn and Digil. ${ }^{4}$ Thus, conflict was largely based on the patron-client network with some clans possessing a marked advantage over others and the oppressive conditions the structure produced.

This paper argues that following, the fall of Mohammed Siad Barre's regime, leaders of different opposition groups mobilized the government, military, and clan structures towards their own political ends, leading to renewed conflict. Two primary protagonists dominated the Somali Civil War; General Mohammed Farah Aideed and Ali Mahdi Mohammed. Secondary protagonists were Mohammed Said Hersi Morgan and Ahmed Omar Jess. Each warlord used the factions they led, the Somali government, military and people as instruments for pursuing their 
political interest. Each political leader's interests and the instruments they used to pursue those interests will be analyzed in three categories: government, military and people. The Somali National Front (SNF), the Somali Patriotic Movement (SPM) and the United Somali Congress (USC) are the three factions the aforementioned leaders led. Most of these groups were bred out of Somali National Movement. ${ }^{5}$ I intend to explain how the faction leaders functioned as political entities inculcating a culture of violence and depravity.

The four leaders indicated above operated at the forefront of the Somali Civil War; they were not all on equal footing or represented an even distribution of rivalry. Instead, two emerged as frontrunners and the other two each supported a contender. Aideed and Mahdi were both frontrunners from the USC. However, through their leadership, the USC represented distinct factions. Jess and Morgan were subordinate to the frontrunners. Jess allied with Aideed while Morgan aligned with Mahdi. Consequently, this paper places more emphasis on Aideed and Mahdi as "supported" leaders with less emphasis on Morgan and Jess as "supporting" leaders.

Since its establishment as a republic in 1960, Somalia has endured a tumorous existence. Neighboring Kenya and Ethiopia engaged in conflict with Somalia. Ethnic Somalis in the northern region of Kenya fought conflicts against the Kenyan government. Known as the Shifta War, these Somalis sought secession from Kenya and unification with Somalia. However, the conflict ended with a ceasefire and no secession. The conflict with Ethiopia was fought over the Ogaden region of Ethiopia between July 1977 and March $1978 .{ }^{6}$ At the time, Ogaden was home to millions of Somali people. Somalia held irredentist claims to the region. However, the conflict ended with Ethiopia maintaining control over the region. While conflicts with other nation states were significant, the period of civil conflict was much more significant and divisive for Somalis. 
But before getting into the internal hostilities, it's important to first understand how Mohammed Siad Barre rose to power in 1969.

Barre rose through the ranks as a gendarme. He displayed unethical behavior by western standards throughout his career beginning with his first promotion to First Gendarme. Facing disciplinary actions from his noncommissioned officer (NCO) instructor during the BMA, Barre struck a deal with the British officer Somali interpreter. When the NCO brought Barre before the British Officer for discipline, instead correctly interpreting the details of the infraction, the interpreting lied stating Barre was "Very smart". Unable to speak the true nature of the infraction, the NCO stood by as the British officer promoted Barre instead of disciplining him. ${ }^{7}$ There were other accounts of deceit which provided early indications of how unscrupulous Barre was before he rose to power.

Barre, a member of the Darod clan, seized power during a 1969 bloodless coup d'état against Interim President Mukhtar Mohamed Hussein, who had only held office for six days. Hussein's brief presidency was a result of the October 15, 1969 assassination of President Abdirashid Ali Shermarke. Barre advocated scientific socialism for Somalia, a political philosophy described as a contrived and awkward marriage of neo-Marxism and nationalism. ${ }^{8}$ He vowed to eliminate rampant corruption, restore security and stability and push an agenda of reconstruction based on self-reliance. ${ }^{9}$ Comparing himself to the Shermarke regime, Barre commented "Injustice and maladministration, lack of social progress and economic development, coupled with a sinking national morale, compelled us to bring about a change." 10 One of his first acts as dictator was to ban tribalism by making it a criminal act to both publicly and privately acknowledge existence of clans or payment of diya. Diya is the financial compensation paid to the victim or heirs of a victim in the cases of murder, bodily harm or property damage. ${ }^{11}$ 
Violators were subject to arrest. Ironically, faction leaders could echo these earlier critiques when discussing Barre's regime when he was ousted from power.

The Barre regime's undoing can be attributed to the classic case of overpromising and under delivering. The actions taken by the regime's top administrative and military echelons, and increasingly, Barre's closest family, were “blatantly illegal, immoral, and expressive of enormous contempt for the common people."12 For those outside of Barre's inner circle, conditions were incredibly dire. Both in the cities and countryside, people grew more and more impoverished. Middle-class citizens could no longer afford basis amenities such as fuel for their cars. Farmers saw their capacities diminish as larger developments operating due to corrupt state officials forced their displacement. Injustice and corruption bred further violence and greed under Barre.

Regime and personal loyalty was valued more than skill and merit is just one example. Perhaps more telling was Barre's belief that his regime was indivisible, accountable to no one and superior to any other political ideology. Nonetheless, Barre did hold on to power for more than 20 years until 1991. Opposition groups that set aside their differences and composed a united front that ultimately overthrew him. But why did the united opposition groups that ousted Mohammed Siad Barre's regime then devolve into fighting after the fall of Barre's regime? A closer examination of Aideed, Mahdi, Jess and Morgan follows to explain.

\section{- General Mohamed Farah Hassan Aideed and United Somali Congress}

Mohammed Farah Aideed was a military leader in the Somali army. He was a member of the Habar Gidir sub clan of the Hawiye based largely in the central Somalia. ${ }^{13}$ Aideed was a learned military officer who was trained by both the Italians and Soviets. Barre was from the 
Marrehan clan which is a sub clan of Darod based primarily in the north-east and southern regions. ${ }^{14}$ He considered Aideed a threat to his efforts as Aideed had similar aspirations of leading Somali's military. Rightfully so, there is some evidence that Aideed informed President Shermarke's administration that a coup led by Barre was imminent October 20, 1969. However, once the news reached the Minster of the Interior, Yassin Nur, Aideed's advisement was dismissed. ${ }^{15}$ At the time of independence, Barre won appoint as the head of the armed forces because he was senior to Aideed. Yet Barre had Aideed pre-emptively arrested as he considered him a threat and suspected he was planning his own coup d'état. Aideed remained in prison for six years. His release was out of necessity. Barre needed competent military officers to fight in the Somali-Ethiopian War from 1977-1978.

Aideed fought the Ethiopians and at the conclusion of the war, Barre assigned him to diplomatic duties, sending him on various overseas postings as military attaché. ${ }^{16}$ The end of the conflict over the Ogaden meant the start of the Civil War. Now a clear opponent to Barre, Aideed became the leader of the United Somali Congress (USC) military wing. Aideed played an active role in deposing Barre's presidency. Consequently, he expected to emerge as victory in seceding Barre as Somalia's next president. While overtly advocating a democracy political system, Aideed followed Barre's lead by favoring his own clan over the rights and recognition of other clans. This allowed him to exert a level of legitimacy as a state leader. His stated vision for Somalia was a modern democracy where clan affiliation did not dominate Somali politics and society. Aideed envisioned a kind of democracy in which people would have a very direct say on political affairs:

"We have to realize that the model of healthy and functional democracy that we are planning to adopt in Somalia is such that every one will have perfect autonomy and 
satisfaction of serving the nation whole-heartedly, and no one will be able to exploit the people by becoming President, Prime Minster or a big boss." ${ }^{17}$

The USC was created in 1989 as a primarily Hawiye organization. Hawiye was a deliberate choice by the founding elders who recognized they made up the foundation of the Mogadishu business community and were the largest clan. More importantly, they were also subjected to Barre's oppressive regime and did not believe a lasting truce with him was possible. Barre systematically manipulated clan-based violence targeting civilians to keep the opposition against him divided. His actions had the strategic effect of galvanizing clan-based identities, making equality and differences more distinct and exploitable. Further, clans not subject to Barre manipulation were left with a false sense of security that they were exempted or immune from Barre's government harassment. ${ }^{18}$ Barre's coercing of civilians highlighted the political and social costs of opposing his rule. The intended outcome of his coercion was to making the cost of supporting the opposition greater than the reward. Aideed was serving as Ambassador to India, Sri Lanka and Singapore when he was asked to lead the USC armed opposition. Aideed based his effort in Ethiopia, formed his own branch of the USC and began recruiting former soldiers who had defect from the Somali National Army in addition to mujahidin (jihad fighters). ${ }^{19} \mathrm{He}$ also formed a close and formal relationship with Somali National Movement (SNM).

The USC was initially organized on two fronts, one based in Mogadishu and the other in Rome, Italy. The Rome contingent focused on publicity and mobilization. However, the Mogadishu contingent made the all decisions of any importance. The dual front effort devolved into turmoil within USC. The leaders on both fronts died; Ali Wardhigley in April 1990 and Dr Ismail Jumale in July of the same year. 1990. Their deaths created a leadership vacuum that 
began a power struggle for control of the USC. Aideed and Hussein Ali Shido considered themselves successors to Dr Jumale and Wardhigley respectively.

Neither Mogadishu nor Rome USC elements considered Aideed worthy of leading the USC. Regarding the Rome wing, Aideed never considered that element to be more than simple demagogues. Thus Aideed traveled to Ethiopia and acquired the title of interim USC Chairman from the forces he commanded. Recognizing the threat Aideed posed for the larger Hawiye clan, both wings cooperated to deny Aideed's authority to represent USC in any form. In a joint statement regarding the post-Barre dictatorship era, the Executive Committee of the USC denounced that multilateral agreement between the USC, the SNM and the SPM that had served well as each group cooperated to depose Barre. Now with Barre ousted, USC's position on Aideed, the foundation for conflict amongst clans and to larger extent, amongst Hawiye subclans was now inevitable. ${ }^{20}$

\section{- Ali Mahdi Mohammed and United Somali Congress}

Mahdi was a prominent businessman in Mogadishu. He was from the Abgal sub-clan of the Hawiye. Aideed's election as USC Chairman was also an attempt to subjugate his authority. External influences from Italy encouraged another USC leader, Ali Mahdi to declare himself interim president of Somalia. Mahdi vowed to "give first priority to the interests of the Somali people and their unity before anything else, with respect for the sacred religion and the age-old heritage of the Somali nation."21 Opposition groups, including the SNM, opposed Mahdi's claim of interim president. Their opposition was largely personality driven. Each group understood that the group in power had the most to gain in terms of power and influence. But the USC was 
hopeful that Aideed would accept Mahdi with the caveat that Mahdi would consult Aideed on all major policy and appointment decisions. ${ }^{22}$.

Unfortunately, that was not an acceptable compromise for Aideed and he did not acquiesce to Mahdi's offer. Instead, Hawiye sub-clan conflict between Mahdi's Abgal clan and Aideed's Habar Gedir clan ensued. Mogadishu was reduced to a war zone...”that divides northern and southern Mogadishu between warring factions. The area between them has become a ghost town, haunted by the memories of splendor and of failure. The hopes of the one-time residents have been crushed and twisted beyond repair, like the metal gates to the local palaces of commerce, art and religion. ${ }^{\text {“23 }}$ Aideed's information operations (IO) strategy was effective against Barre's regime. Aideed's target audience for recruitment was about more than recruiting militia and defected fighters. Aideed's IO campaign focused on anti-Darod rhetoric perpetuating the view that the clan represented "all urban wealth and power." 24 This representation was not difficult for Aideed to support considering at the time of Barre's fall, of the 103 key leadership positons held in the Barre regime, 56 were Darod followed by 25 Hawiye clan positions. ${ }^{25}$

Aideed's USC faction target of the opposition and the civilians that composed them did not enjoy the sanctity of security typically afforded to noncombatants. This was true of all opposition groups ${ }^{26}$ Between the two USC factions lead by Aideed and Mahdi, reportedly 14,000 people died and 27,000 were wounded from November 1991 to February 1992 alone. $^{27}$ The northern region's SNM saw Mahdi's interim presidency as another example of southern arrogance. Largely composed of the Isaq clan-family, SNM forces had previously waged war against the Barre regime and capturing the countryside. The SNM supported Aideed's USC forces. However, following Mahdi's declared position, the SNM consider USC a better alternative to Barre. ${ }^{28}$ 
Aideed and Mahdi both financed their war efforts and accumulated wealth during the civil war by preying on the Somali people. In the case of Mahdi, he financed his faction's fight against Aideed and his alliance with proceeds from the khat drug trade. Grown primarily in Kenya and Ethiopia, khat is a legal narcotic stimulant widely accepted as a part of the Somali culture. As the war progressed and conditions in the country worsen, khat as a commodity became more and more profitable. Estimates ranged from one to five million dollars worth of khat drugs traded every month. Mahdi enabled khat export by allowing the use of several planes to transport the drug from Kenya. ${ }^{29}$ On the other hand, Aideed exploited the humanitarian aid and food supplies to finance his effort. He manipulated NGO support by inflating the number of Somali people in need. For example, his officials grossly inflated the figures to Care and UNICEF for displaced people in Bardera, doubling the requirement from the actual need. ${ }^{30}$ While in other areas, Aideed reduced the amount of aid requested from the true need to a much smaller number to discourage support in an area, thus denial assistance to an area Aideed sought to exert more control over. For both leaders, the ability to gather and/or manipulate resources translated into the presence and use of subversive power over the Somali people. In a culture where "rich men are powerful and powerful men are rich," Aideed and Mahdi exercised an unscrupulous ability to increase their legitimacy my exploiting and exacerbating the dire conditions of Somalis.

\section{- Mohammed Said Hersi Morgan and the Somali National Front}

Mohammed Said Hersi Morgan was a military commander in the Somali armed forces and later commanded the Somali National Front (SNF) following Barre's fall. Morgan married into the Barre family by wedding one of his daughters. He received military training from the US 
as a part of military aid package provided to Somalia in the early 1980s. ${ }^{31}$ Morgan commanded Somali forces in the north when SNM fighters invaded northern Somalia from Ethiopia in 1988. He was a member of the Marehan sub-clan that was apart of the Darod clan. During the civil conflict, Morgan based his SNF fighters in southern Somalia, which also constituted the heartland of Barre supporters. ${ }^{32}$ SNF's existence had a galvanizing effect of most of Somalia as it represented the repressive Barre regime. It would have been more galvanizing except Aideed and Ali Mahdi’s USC factions were too busying battling each other. Morgan would enjoy small victories such as capturing Kismayo, the main costal trading town in the south. ${ }^{33}$ However, he later lost control of the town to Jess. The only thing that unified the other factions more than defeating Barre supporters was defeating non-Somali intervention. In that case, each faction setaside their differences long enough to expel international forces. Morgan was no exception.

\section{- Ahmed Omar Jess and the Somali Patriotic Movement}

Ahmed Omar Jess and his rivalry with Morgan has already been discussed, but it is appropriate to further frame who Jess was and the role he played in leading the Somali Patriotic Movement(SPM). SPM was primarily composed of the Ogadeni sub-clan and was created out of displeasure with the Barre regime. In January 1989, Barre dismissed the Ogadeni Minister of Defence and had him arrested. Further, Barre brokered an agreement with Ethiopia. The agreement was at odds with the Ogadeni's goal of liberating the Ogaden region from Ethiopia.

Jess was an Ogadeni army commander that deserted from the army, taking his men with him. Jess initially joined the SNM and later became a part of the SPM as its military commander. Under Jess' command, SPM captured territory on the Kenyan border in 1989 and faced Barre forces in the south. When Barre's regime collapsed, Jess and SPM, like Aideed, opposed 
Mahdi's appointment of interim president. By 1994 the Jess faction of SPM effectively had ceased to function and the elders had begun to reconcile their differences with the Aulihan and Marehan clans through independent negotiations. ${ }^{34}$

Morgan and his most significant rival in the south, Ahmed Omar Jess, both exploited subclan grievances as a means to bolster recruitment. Particularly, Morgan focused on recruiting Harti traders while Jess recruited Ogadeni herders. ${ }^{35}$ Both sub-clans are apart of the Darod family, a fact that will be prove disastrous for Kismayo. "With each advance or retreat, marauding armies and their thousands of armed camp followers looted and pillaged without restraint....Destruction was systematic, with wells, ponds, grain stores, seeds and livestock consumed, carried off, killed, or destroyed. The people of the agriculturally productive Jubba Valley were "repeatedly victimized by the scorched-earth tactics of...militias as their forces looted livestock, seeds, tools, and grain, destroyed water sources, raped the women and killed the men." 36

Morgan was eventually defeated by Aideed's USC and forced to flee to Kenya in May of 1992. ${ }^{37}$ However, his defeat did not equal the end of SNF. Instead, Morgan re-entered the war after regrouping in Kenya. Exploiting a captive audience of refugees, he recruited new SNF fighters and re-entered Somalia taking back strategic territory held by Aideed's USC. By October of 1992, Morgan joined an alliance led by Mahdi. His opponent, Jess, joined an alliance led by Aideed.

The Aideed and Jess alliance exploited the Ogadeni and Harti grievance. Specifically, they employed a clan cleansing strategy as political tool in Kismayo on the eve of US troops arriving in the coastal town on December 19, 1992. They sought to exterminate the most distinguished male citizens of the city who were all Harti. ${ }^{38}$ More than 100 religious leaders, 
business executives, a doctor and other prominent residents were killed over the course of three nights. Jess is quoted as stating "the town needed to be 'cleared' of people who would cause trouble." ${ }^{39}$ The political motivations for the clan cleansing was geared at gaining leverage over Somali politics before the international forces arrived. Through killing middle-class civilians of the clan-base they associated with Morgan and Mahdi, they undermined the position of their opponents and any other approach to resolving local conflict and the competition for power.

Aideed and Jess enjoyed two immediate advantages following the Kismayo massacre. The first advantage concerned the limitations posed by the UN Security Council (UNSC) resolution. The UNSC did not give intervening forces the authority to make arrests for war crimes. Instead, UNSC resolution encouraged Somalia's traditional approach of consulting elders to engage in governances. But for Kismayo, the local leaders the UNSC resolution sought to bolster were the same residents Aideed and Jess had ordered killed. The second strategic advantage the clan cleansing provided Mahdi and Morgan rivals was that it eliminated the only opportunity Kismayo had to replace clan-based violence with a cross-clan or clan agnostic identity. The men murdered represented the Kismayo's opportunity to set aside clan-based grievances and establish a new urban and unity identity. The Kismayo atrocity was largely a Darod clan experience. However, it was not the first large-scale example. Forces within the Aideed and Mahdi factions participated in similar cleansing before the Kismayo tragedy. Although popular support for the brutal "leadership" of either Morgan or Jess is probably minimal, their tactics have been able to capitalize on existing tensions and rivalries over trade and production, allowing them to pursue their own agendas. ${ }^{40}$

Clan cleansing was employed as a political strategy against the citizens in Mogadishu. Aideed used the people of Mogadishu in several ways to further his political agenda. He 
mobilized rural fighters against the Barre's clan by promising the fighters the spoils of the city because it was ill-gotten wealth based on the Barre regime and clan's exploitation of others. This tactic also served the purpose of providing compensation to the Aideed fighters. They simply ravaged the city and its Darod occupants. Fighters committed violence against civilians as a matter of standard operating procedure. Aideed made the Darod clan synonymous with the Barre regime. Members of Darod could no longer separate themselves from the stigma attached to the Barre regime, even if they had not benefited from his rule. "The civilians making up its clan-base had been severely ill-treated by Barre at a time at which those associated with the USC had ben allowed to prosper economically. A policy of clan cleansing against 'the' Daarood (sic) was for men like...Caydiid (sic) a strategy of making room at the top." ${ }^{41}$ Effectively, Aideed incentivized normal citizens' participation in the isolation and extermination of his Darod rivals. 


\section{- Conclusion}

The period of the Somali Civil War from 1991-1995 is externally described as "a ward of the international aid community." But more critical to Somalis, internally, Somalia is best described as a nation that devolved into a state of repression and expropriation. Faction leaders exploited clan grievances that existed before Barre's regime and used the people as political tools to strengthen their own hold on power and territory were undermining the same for their rivals. Leaders used khat and food supplies to increase their own coffers favoring those clans or groups that displayed allegiance to their cause. Stated differently, "civil servants clever, powerful or well-connected enough to place themselves at strategic spigots in the foreign aid pipeline."42

The Aideed and Mahdi's faction of USC opposed each other while dominating the provisional government. Hawiye clan in central Somalia composed most of the USC supportbase. SPM, led by Jess was strongest among the Ogadeni clan of southern Somalia. Meanwhile, Morgan's SNF was largely made up of members of the Harti clan. ${ }^{43}$ The case of Somalia reflects African leaders' attitudes toward territorial integrity. From 1991 to at least 2012, Somalia has had no effective central government. ${ }^{44}$ 


\section{Notes}

${ }^{1}$ Adam, Hussein. From Tyranny to Anarchy, the Somali Experience. Eritrea, The Red Sea Press, 2008. 88.

${ }^{2}$ Duyvesteyn, Isabella. Clausewitz and African War. London, Frank Cass, 2005. 37

${ }^{3}$ Duyvesteyn, 38.

${ }^{4}$ Lewis, Ioan. Understanding Somalia and Somaliland. New York, Columbia University Press, 2008. 109.

${ }_{6}^{5}$ Adam, 88.

${ }^{6}$ Clayton, Anthony. Frontiersmen: Warfare in Africa since 1950. London, Routledge, 1999. 102.

${ }^{7}$ Ghalib, Jama Mohamed. The Cost of Dictatorship. New York, Lilian Barber Press, 1995. 119

${ }^{8}$ Samatar, Ahmed I. The Somali Challenge: From Catastrophe to Renewal? Colorado, Lynne

Rienner Publishers, 1994. 120.

${ }^{9}$ Ghalid, 121.

${ }^{10}$ Ghalid, 121.

${ }^{11}$ Lewis, I.M. A Modern History of the Somali. Athens, Ohio University Press, 2002. 208

${ }^{12}$ Kapteijns, Lidwien. Clan Cleansing in Somalia. Philadelphia, University of Pennsylvania Press, 2013. 203.

${ }^{13}$ Lewis, 73.

${ }^{14}$ Duyvesteyn, 55.

${ }^{15}$ Ghalid, 120.

${ }^{16}$ Duyvesteyn, 41.

${ }^{17}$ Duyvesteyn, 42.

${ }^{18}$ Kapteijns, 194.

${ }^{19}$ Kapteijns, 98.

${ }^{20}$ Ghalid, 195.

${ }^{21}$ Kapteijns, 150.

${ }^{22}$ Adam, 92.

${ }^{23}$ Schemo, Diana. "On Mogadishu's 'Green Line,' Nothing Is Sacred." The New York Times, February 14, 1993.

${ }^{24}$ Kapteijns, 98.

${ }^{25}$ Adam, 121.

${ }^{26}$ Kapteijns, 179.

${ }^{27}$ Kapteijns, 179.

${ }^{28}$ Adam, 121.

${ }^{29}$ Duyvesteyn, 83.

${ }^{30}$ Duyvesteyn, 83.

${ }^{31}$ Duyvesteyn, 43.

${ }^{32}$ Duyvesteyn, 43.

${ }^{33}$ Duyvesteyn, 45

${ }^{34}$. Little, Peter D. "Conflictive Trade, Contested Identity: The Effects of Export Markets on Pastoralists of Southern Somalia." African Studies Review 39.1 (1996): 46.

${ }^{35}$ Duyvesteyn, 57. 
${ }^{36}$ Besteman, Catherine. Violent Politics and the Politics of Violence: The Dissolution of the Somali Nation-State. American Ethnologist, Vol. 23, No. 3 (Aug., 1996). American

Anthropological Association. 582.

${ }^{37}$ Kapteijns, 187.

${ }^{38}$ Kapteijns, 188.

${ }^{39}$ Kapteijns, 189.

${ }^{40}$ Little, 49.

${ }^{41}$ Kapteijns, 199.

${ }^{42}$ Menkhaus, Ken. "Governance Without Government In Somalia: Spoilers, State Building, And The Politics Of Coping." International Security 31, no. 3, 80.

${ }^{43}$ Volman, Daniel. "Africa and the New World Order." The Journal of Modern African Studies, Vol. 31, No. 1 (Mar., 1993), 7.

${ }^{44}$ Victor, J. "African Peacekeeping in Africa: Warlord Politics, Defense Economics, and State Legitimacy." Journal of Peace Research, 2010. 223. 


\section{Bibliography}

Adam, Hussein. From Tyranny to Anarchy. Trenton NJ: Red Sea Press, 2000.

Besteman, Catherine. "Violent Politics and the Politics of Violence: The Dissolution of the Somali Nation-State.” American Ethnologist, Vol. 23, No. 3 (Aug., 1996), pp. 579-596. American Anthropological Association.

Duyvesteyn, Isabella. Clausewitz and African War. London: Frank Cass, 2005

Höhne, Markus V. "Political Identity, Emerging State Structures and Conflict in Northern Somalia." The Journal of Modern African Studies 44, no. 3 (2006): 397-414.

Kapteijns, Lidwien. Clan Cleansing in Somalia. Philadelphia: University of Pennsylvania Press, 2013.

Lewis, I.M. A Modern History of the Somali. Athens, Ohio University Press, 2002.

Lewis, Ioan. Understanding Somalia and Somaliland. New York, Columbia University Press, 2008. 109.

Little, Peter D. "Conflictive Trade, Contested Identity: The Effects of Export Markets on Pastoralists of Southern Somalia." African Studies Review 39.1 (1996): 25-53. JSTOR. Web. 01 Apr. 2015.

Marchal, Roland. "Warlordism and terrorism: how to obscure an already confusing crisis? The case of Somalia." International Affairs 83, no. 6 (November 2007): 1091-1106.

Menkhaus, Ken. "Governance Without Government In Somalia: Spoilers, State Building, And The Politics Of Coping." International Security 31, no. 3, 74-106.

Schemo, Diana. "On Mogadishu's 'Green Line,' Nothing Is Sacred." The New York Times, February 14, 1993.

Victor, J. "African Peacekeeping in Africa: Warlord Politics, Defense Economics, and State Legitimacy." Journal of Peace Research, 2010, 217-29.

Volman, Daniel. "Africa and the New World Order." The Journal of Modern African Studies, Vol. 31, No. 1 (Mar., 1993), pp. 1-30. Published by: Cambridge University Press.

Wallensteen, Peter and Sollenberg, Margareta. "Armed Conflicts, Conflict Termination and Peace Agreements, 1989-96." Journal of Peace Research Vol. 34, No. 3 (Aug., 1997), pp. 339-358. Sage Publications, Ltd. 